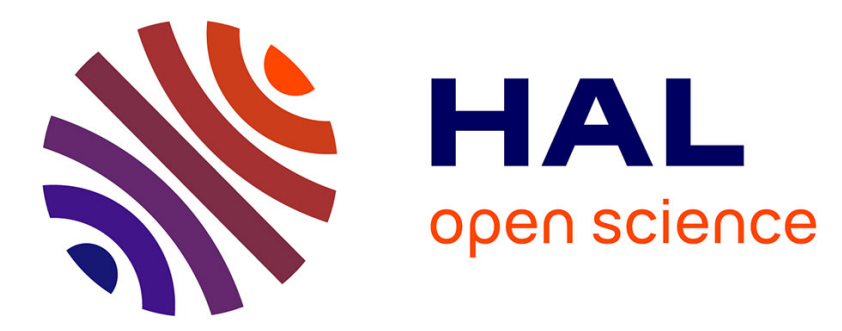

\title{
Improvement of the binding capacity of metal cations by sugar-beet pulp. 2. Binding of divalent metal cations by modified sugar-beet pulp
}

\author{
V.M. Dronnet, Monique Axelos M.A.V., C.M.G.C. Renard, J.F. Thibault
}

\section{- To cite this version:}

V.M. Dronnet, Monique Axelos M.A.V., C.M.G.C. Renard, J.F. Thibault. Improvement of the binding capacity of metal cations by sugar-beet pulp. 2. Binding of divalent metal cations by modified sugarbeet pulp. Carbohydrate Polymers, 1998, 35, pp.239-247. hal-02697342

\author{
HAL Id: hal-02697342 \\ https://hal.inrae.fr/hal-02697342
}

Submitted on 1 Jun 2020

HAL is a multi-disciplinary open access archive for the deposit and dissemination of scientific research documents, whether they are published or not. The documents may come from teaching and research institutions in France or abroad, or from public or private research centers.
L'archive ouverte pluridisciplinaire HAL, est destinée au dépôt et à la diffusion de documents scientifiques de niveau recherche, publiés ou non, émanant des établissements d'enseignement et de recherche français ou étrangers, des laboratoires publics ou privés. 


\title{
Improvement of the binding capacity of metal cations by sugar-beet pulp. 2 . Binding of divalent metal cations by modified sugar-beet pulp
}

\author{
V.M. Dronnet, M.A.V. Axelos, C.M.G.C. Renard and J.-F. Thibault"* \\ Institut National de la Recherche Agronomique, Centre de Recherches Agro-Alimentaires, rue de la Géraudière, \\ B.P. $71627-44316$ Nantes Cedex 3, France
}

(Received 14 April 1997; accepted I August 1997)

\begin{abstract}
Binding of some divalent cations $\left(\mathrm{Ca}^{2+}, \mathrm{Cd}^{2+}, \mathrm{Cu}^{2+}, \mathrm{Ni}^{2+}, \mathrm{Pb}^{2+}\right.$ and $\left.\mathrm{Zn}^{2+}\right)$ in aqueous Binding by saponified and cross-linked sugar-beet pulp was investigated. Saponification doubled the cation-exchange capacity, while cross-linking decreased specific surface area and hydration properties to low and stable values independent of $\mathrm{pH}$ and ionic strength conditions. The sorption isotherms indicated a high metal-binding capacity which increased with sorbent concentration, and followed a clear order of sclectivity: $\mathrm{Cu}^{2+} \sim \mathrm{Pb}^{2+} \gg \mathrm{Zn}^{2+} \sim \mathrm{Cd}^{2+}>\mathrm{Ni}^{2+}>\mathrm{Ca}^{2++}$. The sorption data were better represented by the Langmuir isotherm than by the Freundlich one, suggesting that the monolayer sorption, mainly due to ion-exchange, would not be disturbed by lateral interactions between cations sorbed with similar sorption energies. The same order of sclectivity could be drawn from the Langmuir parameters, sorplion equilibrium constants $\left(K_{\mathrm{L}}\right)$ and maximum binding capacitics ( $\left(\mathrm{Mc}_{\mathrm{A}} \max \right)$. Whatever the cation, $K_{\mathrm{L}}$ decreased with increasing sorbent concentration, while $\mathrm{Me}_{\mathrm{b}} \max$ increased. Higher quantities of $\mathrm{Cu}^{2+}$ and $\mathrm{Pb}^{2+}$ than predicted by the one divalent cation to two carboxyl functions ratio were bound. This was attributed to the partial contribution to the sorption phenomenon of hydroxyl functions close to ionic sites, explaining the higher affinity of such eations for substrates. Cross-linked pulp exhibited higher metalbinding capacity per volume unit than the raw pulp. (C) 1998 Elsevier Science Ltd. All rights reserved
\end{abstract}

\section{INTRODUCTION}

The industrial application of conventional separative and physico-chemical techniques for removal of toxic metals from industrial effluents is restricted by the cost of the sorbent (chelating or ion-exchange resins obtained by grafting of functional groups onto carrier polymers), by the operating costs (membrane techniques), by creating sludge disposal problems or by the inefficiency of techniques in reaching standards specific to a given branch of industry. Effluents with residual metal concentrations in the range from 1 to over $100 \mathrm{mg} \mathrm{l}^{-1}$ can effectively and economically be

*To whom correspondence should be addressed. Tel.: +33 2 40675060; fax: +332 40675066; e-mail: thibault@nantes.inra.fr epurated by using bioresources. Both bioaccumulation and biosorption may occur when natural substrates are used for netal sequestering (Volesky, 1990). Bioaccumulation is the active mode of metal uptake by living cells. It depends on the metabolic activity of the cell and its capability for adapting to the presence of metal ions in its environment. Biosorption is metal uptake by dead cells, or cell debris such as isolated cell-wall, via a number of physico-chemical mechanisms (Volesky, 1990). It implies a metabolic-independent mode of metal uptake and is thus not complicated by coordinating cell growth and propagation in the presence of toxic metal ions (Huber et al., 1990). The key intrinsic features of a suitable biosorbent are: high metal-binding capability, low and stable hydration properties, resistance to external parameters such as $\mathrm{pH}$ or solvent conditions. Among substrates investigated for this purpose have been: 
agricultural and forestry waste products (Kumar and Dara, 1982; Marshall et al., 1993; Vazquez et al., 1994), algae (Holan et al., 1993; Holan and Volesky, 1994), microbial biomass (Chang and Hong, 1994) and filamentous fungi (Guibal et al., 1992).

Biosorption may be a way of increasing the value of agricultural by-products which contain high amounts of cell-wall material. An example of such a by-product is sugar-beet pulp, which is produced in large amounts at low cost in a reliable and constant supply. It is obtained after sucrose extraction and consists mainly in cell-wall of sugar beet. It is very cheap and its production reaches $1.6 \times$ $10^{6}$ tonnes of dry matter per year in the EU. A few studies on the binding of metal cations by beet pulp have been carried out (Langenhorst et al., 1961; Sharma and Forster, 1994). More recently, we have performed preliminary studies on raw beet pulp (Dronnet et al., 1997). It exhibited high metal-binding properties, linked to its high amount of pectic substances $\left(>40 \mathrm{~g} \mathrm{~kg}^{-1}\right)$, and a clear scale of selectivity (Dronnet et al., 1996). However, beet pulp displayed high hydration capacities and, therefore, a low binding capacity per unit volume. Hence, enhancement of metal cation sorption performances of beet pulp was investigated either by increasing the cation-exchange capacity (saponification) and/or by decreasing hydration properties (cross-linking treatments by formaldehyde or epichlorohydrin) as reported in the accompanying article (Dronnet et al., 1997). Saponification doubled the cation-exchange capacity (to $1.13 \mathrm{meq} \mathrm{g}^{-1}$ ) without modifying the sugar composition or decreasing the hydration properties $\left(\sim 32 \mathrm{ml} \mathrm{g}^{-1}\right.$ at $\mathrm{pH} \sim 7$ in water). Treatment with formaldehyde had little effect on hydration properties. The best results in terms of hydration capacity were obtained after treatment with epichlorohydrin, which lowered swelling and water-retention capacities to $7 \mathrm{mlg}^{-1}$ and $2 \mathrm{~g} \mathrm{~g}^{-1}$, respectively. This effect was independent of $\mathrm{pH}$ and ionic strength when the molar ratio epichlorohydrin/total sugars exceeded 10 , and resulted in a material with a cation-exchange capacity (CEC) of $0.97 \mathrm{meq} \mathrm{g}^{-1}$.

In this article, we characterized the metal cation binding properties of saponified pulp and saponified pulp treated with epichlorohydrin with a molar ratio of 10 in order to highlight the effects of the similar CECs but different hydration capacities of these two sorbents. The fraction of metal cations entraped by sorbents was indirectly quantified by titrating the free metal cation concentration at equilibrium. Both Langmuir and Freundlich sorption isotherms were applied to the experimental results.

\section{MATERIALS AND METHODS}

\section{Sórbents}

The raw sugar-beet pulp was supplied by Générale Sucrière (France) and cleaned as detailed elsewhere (Dronnet et al., 1997). The saponified form of beet pulp was obtained after an alkaline treatment at $\mathrm{pH} \geq 13$ for $2 \mathrm{~h}$ at $4^{\circ} \mathrm{C}$ (Dronnet et al. 1998). The saponified pulp ( $5 \mathrm{~g}$ ) was treated by epichlorohydrin for $1 \mathrm{~h}$ in a mixture of $95 \%$ ethanol/ $5 \mathrm{~mol} \mathrm{I}^{-1} \mathrm{NaOH} / \mathrm{epichlorohydrin}(60 / 40 / 20.4 \mathrm{ml})$ corresponding to a molar ratio epichlorohydrin/total sugars = 10. Analytical methods were as described earlier (Dronnet et al., 1997). The swelling capacity (SC) was measured by the bed volume technique (Kuniak and Marchessault, 1972), the watcr-retention capacity (WRC) as water retained alter centrifugation (MacConnell et al., 1974), the specific surface area according to the BET method (Brunauer, 1945). The conversion to the acidic form of sorbents was explained elsewhere (Dronnet et al., 1997). CEC $C_{\text {exp. }}$ is the total number of ionic sites $\left(\mathrm{meq}^{-1}\right.$ ) carried by the sorbent, previously put in the acidic form, and determined by $\mathrm{pH}$-metry (Bertin et al., 1988).

\section{Sorption studies}

Sorption experiments were carried out by adding solutions of the metal cation to suspensions of modified pulp (sorbent) in batch assays. Sorbents, in their acidic form, were stirred to complete hydration in $0.1 \mathrm{~mol} \mathrm{I}^{-1} \mathrm{NaNO}_{3}$ for $1 \mathrm{~h}$. The $\mathrm{pH}$ was then adjusted to $\sim 7.2$ by adding $0.1 \mathrm{~mol}^{-1} \mathrm{NaOH}$ in order to have all carboxyl functions in their sodium salt form. Varying amounts of a 0.1 mol $1^{1-1}$ solution of metal cation were then added to the suspensions. All metal cations were used as their nitrate salts. They will be referred to as $\mathrm{Me}^{2+}$ in the text unless a specific cation is concerned, and were expressed in meq $~^{-1}$. The sorbent concentration was also varied and may be expressed either in meq $1^{-1}\left(C_{\mathrm{p}}\right)$ or in $\mathrm{g}^{-1}$ according to the following relation: $\left[C_{p}\right](\text { meq })^{-1}$ ) $=[$ sorbent $]\left(\mathrm{g}^{-1}\right) \cdot \mathrm{CEC}\left(\mathrm{meq} \mathrm{g}^{-1}\right)$. The temperature was set at $25.0 \pm 0.1^{\circ} \mathrm{C}$ and the suspensions were magnetically stirred for $2 \mathrm{~h}$ to reach equilibrium (Dronnet et al., 1997). Partial solubilisation of polymers occurred during sorption. This was quantified by measuring the galacturonic acid (GalA) in solution (Thibault, 1979) and expressed as the percentage of extracted galacturonic acid against the initial galacturonic acid content. $\mathrm{Ca}^{2+}, \mathrm{Ni}^{2+}$ and $\mathrm{Zn}^{2+}$ concentration at equilibrium was evaluated by means of a dualwavelength dye spectrophotometric method (Dronnet et al., 1996). The final metal cation concentration of $\mathrm{Cd}^{2+}, \mathrm{Cu}^{2+}$ and $\mathrm{Pb}^{2+}$ was determined by potentiometry using ionselective electrodes (Radiometer, France) directly immersed in the suspensions as described previously (Dronnet et al., 1997). Calibration was carried out before each experiment with standard metal cation solutions in the presence of $0.1 \mathrm{~mol}^{-1} \mathrm{NaNO}_{3}$. No noticeable sorption was observed onto the glassware and onto the filtration units during sorption experiments. All metal cation solutions were freshly prepared prior to use.

\section{Sorption isotherms}

The data obtained for the sorption of metal cations on saponified and cross-linked pulp were first plotted as 
binding isotherms (Dronnet et al., 1996) expressed as $\left[\mathrm{Me}^{2+}\right]_{\mathrm{v}} /\left[C_{\mathrm{p}}\right]$ versus $\left[\mathrm{Me}^{2+}\right]_{\mathrm{l}} /\left[C_{\mathrm{p}}\right]$ where all concentrations are expressed in meq $\mathrm{l}^{-1}$ and $\left[\mathrm{Me}^{2+}\right]_{\mathrm{b}}$, the bound cation concentration, is calculated according to the formula $\left[\mathrm{Me}^{2+}\right]_{b}=\left[\mathrm{Me}^{2+}\right]_{t}-\left[\mathrm{Me}^{2+}\right]_{f}$ where $\left[\mathrm{Me}^{2+}\right]_{\mathrm{l}}$ and $\left[\mathrm{Me}^{2+}\right]_{\mathrm{f}}$ are the total and the free metal cation concentrations, respectively. The metal cation concentrations were divided by the sorbent concentration, $\left[C_{p}\right]$, in order to highlight a possible sorbent concentration-dependent sorption. Through this representation, a total binding of the starting cation concentration follows a so-called 'stoichiometric isotherm' which plateaus when all ionic sites of the sorbent are saturated, i.e. a ratio of one divalent metal cation per two carboxyl functions.

The data were also fitted to the Freundlich and Langmuir equations, as were previous results on unmodified beet pulp (Dronnet et al., 1997). Both models allow comparison of the metal cation concentration at equilibrium and to the bound metal cation concentration.

The following linearised form of the Freundlich equation was used

$$
\ln \left[\mathrm{Me}^{2+}\right]_{\mathrm{A}}=\ln K_{\mathrm{F}}+n^{-1} \ln \left[\mathrm{Me}^{2+}\right]_{\mathrm{r}}
$$

where $\left[\mathrm{Me}^{2+}\right]_{\mathrm{A}}$ is the amount of metal cations sorbed per gram of sorbent (meq $\mathrm{g}^{-1}$ ), and $K_{\mathrm{f}}$ and $n^{-1}$ are empirical constants characteristic of the system. They are roughly indicators of the adsorption capacity of the sorbent and of the adsorption intensity, respectively.

Langmuir's sorption isotherm (Langmuir, 1918) was also used to characterise the sorption of metal cations on modified beet pulp. The linear form of the equation is

$$
\frac{\left[\mathrm{Me}^{2+}\right]_{\mathrm{f}}}{\left[\mathrm{Me}^{2+}\right]_{\mathrm{A}}}=\frac{1}{\mathrm{Me}_{\mathrm{A}} \max \cdot K_{\mathrm{L}}}+\frac{\left[\mathrm{Me}^{2+}\right]_{\mathrm{r}}}{\mathrm{Me}_{\mathrm{A}} \max }
$$

where $\mathrm{Me}_{A} \max$ is the monolayer capacity (meq $\mathrm{g}^{-1}$ ) and $K_{\mathrm{L}}$ the binding equilibrium constant $\left(1 \mathrm{meq}^{-1}\right)$.

\section{RESULTS AND DISCUSSION}

\section{Characterisation of the sorbents}

Table 1 summarizes the main characteristics of the sorbents (detailed by Dronnet et al., 1997, 1998). The yield is the ratio of the weight of modified pulp to the weight of the initial pulp.

Saponification was performed under mild conditions and was highly specific as already observed by Renard et al. (1994). It led to almost complete removal of acetyl- and methyl-ester groups, doubling the CEC. The specific surface area, sugar components and the SC remained essentially the same as in the raw beet pulp. The WRC was decreased, indicating a loss of the cell-wall structure.

The epichlorohydrin treatment caused only a minor decrease of the CEC. On the other hand, the hydration properties were drastically reduced and became less sensitive to variations in $\mathrm{pH}$ and ionic strength. This was accompanied by a decrease in the specific surface area which was approximately one-third that of the saponified pulp. This cross-linking treatment radically altered the composition of the pulp. The two main causes of this modification are loss of sugars (mainly arabinose), due to harsh alkaline conditions, and binding of the reagent.

\section{Sorption isotherms}

The sorption of the six divalent cations by the saponified and the cross-linked pulps was firstly described using binding isotherms where $\left[\mathrm{Me}^{2+}\right]_{\mathrm{b}} /\left[\mathrm{C}_{\mathrm{p}}\right]$ was expressed against $\left[\mathrm{Me}^{2+}\right]_{1} /\left[C_{\mathrm{p}}\right]$ (Figs. 1 and 2 ). This allowed the degree of saturation of ion binding sites on the sorbent to be evaluated since the cation-exchange capacity of substrates was previously determined. Sorption was studied with two different pulp concentrations: $14.6 \mathrm{~g} \mathrm{l}^{-1}$ and $8 \mathrm{meq}^{-1}$

Table 1. Main characteristics of the initial, saponified and cross-linked pulps ${ }^{a}$

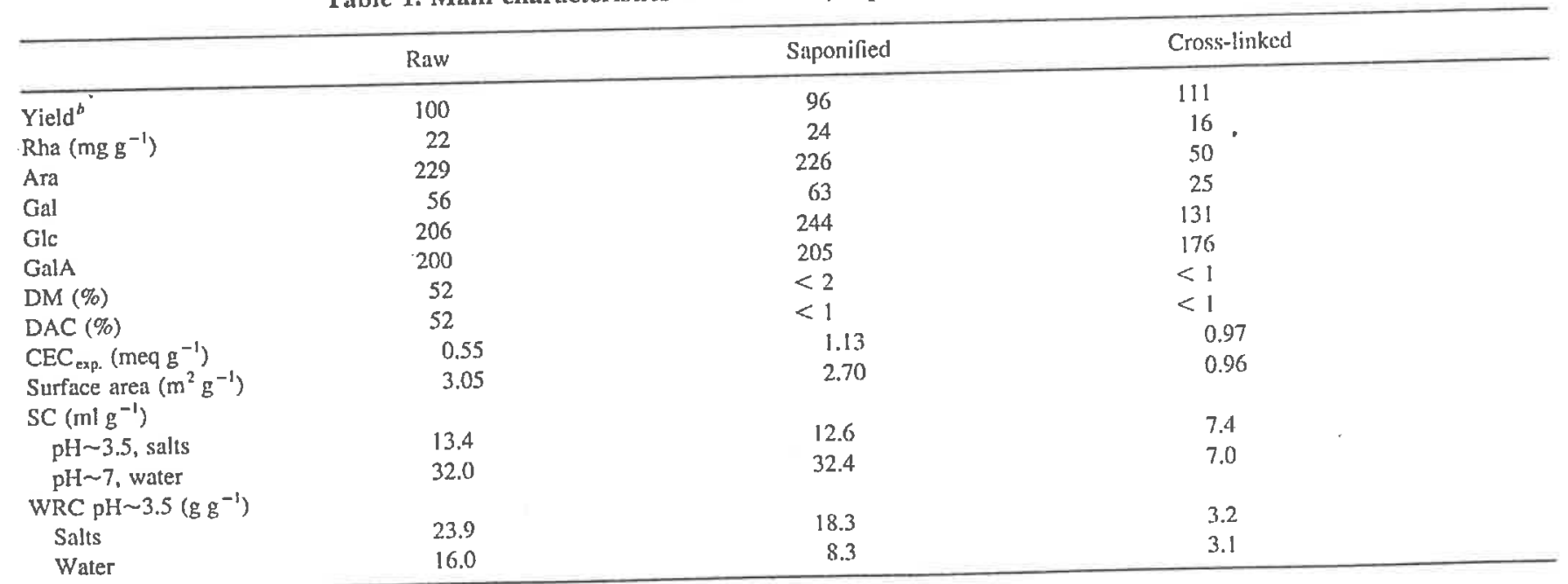

${ }^{a}$ From Dronnet et al. (1997, 1998)

${ }^{b} \%$ of the starting pulp 


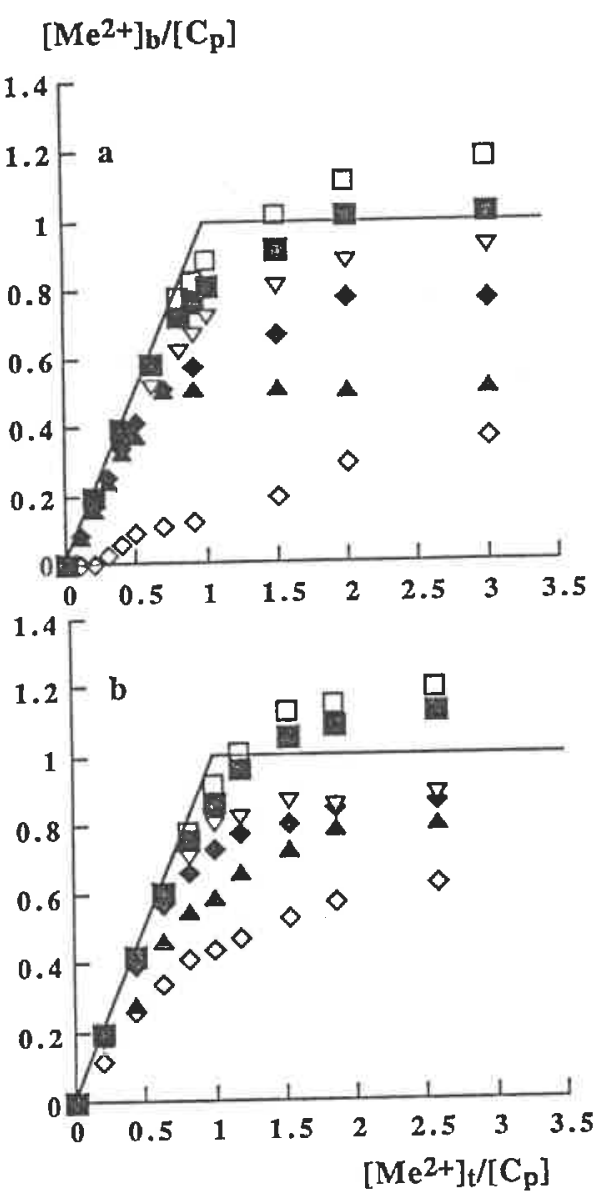

Fig. 1. Influence of the metal cation on the binding isotherms of the saponified pulp in $0.1 \mathrm{~mol}^{-1} \mathrm{NaNO}_{3}$, at $25^{\circ} \mathrm{C}$ and at an initial the saponified pulp in $0.2:(\square) \mathrm{Cu}^{2+},(\mathbf{D}) \mathrm{Pb}^{2+},(\diamond) \mathrm{Zn}^{2+},(\nabla) \mathrm{Cd}^{2+},(\boldsymbol{\Delta}) \mathrm{Ni}^{2+},(\diamond)$ $\mathrm{Ca}^{2+},\left(-(-)\right.$ stoichiometric isotherm; $(a) 7.1$ and $(b) 14.6 \mathrm{~g} \mathrm{t}^{-1}$

(corresponding to 7.1 and $7.5 \mathrm{~g} \mathrm{l}^{-1}$ for the saponified and the cross-linked forms, respectively) in order to compare with the raw pulp for which $8 \mathrm{meq}^{-1}=14.6 \mathrm{~g} \mathrm{l}^{-1}$.

As with soluble pectins (Dronnet et al., 1996) and the raw pulp (Dronnet et al., 1997), the sorption by modified pulps was characterised by curved isotherms which levelled off from a given cation concentration. Plateaus were reached for different $\left[\mathrm{Me}^{2+}\right]_{1}$ according to the metal cation. For both modified pulps, sorption increased with increasing $\left[C_{\mathrm{p}}\right]$, the extent of the increase depending on the metal cation (Dronnet et al., 1997). At low total metal concentrations, steep isotherms were obtained which is highly desirable as they indicate high affinity of the sorbent for the given sorbed species. Very steep isotherms, almost following the stoichiometric isotherm, were obtained at low concentrations of $\mathrm{Cu}^{2+}$ and $\mathrm{Pb}^{2+}$. These plateaued above the stoichiometric isotherm, indicating that higher quantities of such cations may be sorbed than expected from the one $\mathrm{Me}^{2+}$ to two $\mathrm{COO}^{-}$ratio. For a given sorbent concentration, sorption isotherms were found to be higher than with the raw pulp (Dronnet et al., 1997). Alkaline pretreatment of a cyanobacterium also increased metal biosorption from 5 to $34 \%$, depending on the metal cation (Sampedro et al., 1995). An

$$
\left[\mathrm{Me}^{2+}\right] \mathrm{b} /\left[\mathrm{C}_{\mathrm{p}}\right]
$$
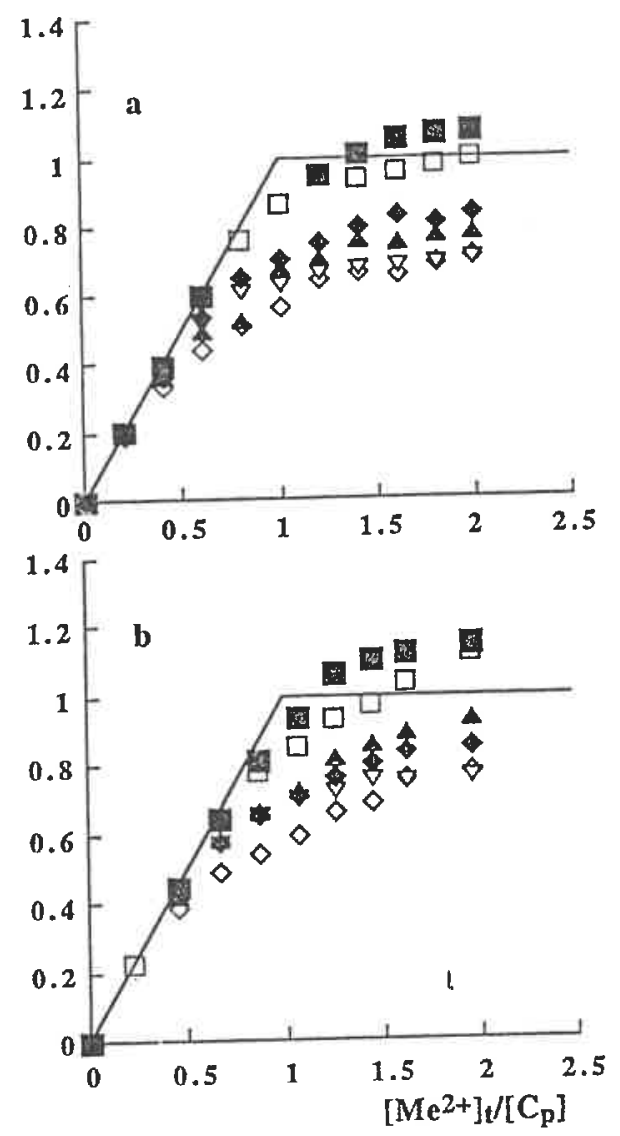

Fig. 2. Influence of the metal cation on the binding isotherms of the cross-linked pulp with epichlorohydrin for a ratio epichlorohydrin/total sugars $=10$, in $0.1 \mathrm{~mol} \mathrm{I}^{-1} \mathrm{NaNO}_{3}$, at $25^{\circ} \mathrm{C}$ and at an

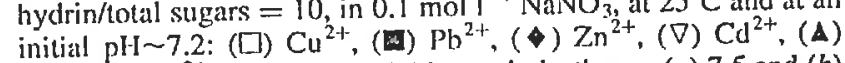
$\mathrm{Ni}^{2+},(\diamond) \mathrm{Ca}^{2+},(-)$ stoichiometric isotherm; $(a) 7.5$ and $(b)$ $14.6 \mathrm{~g}^{-1}$

atypical sorption isotherm was found when the sorption of $\mathrm{Ca}^{2+}$ with the saponified pulp at $8 \mathrm{meq}^{-1}$ was studied: the sorption seemed to start at a given calcium concentration and to plateau very rapidly as in the case of the raw pulp (Dronnet et al., 1997). However, the sorption started for a lower $\left[\mathrm{Ca}^{2+}\right]_{l} /\left[C_{\mathrm{p}}\right]$ ratio than with the raw pulp. When the sorption of $\mathrm{Ca}^{2+}$ was carried out with the saponified pulp at $14.6 \mathrm{~g} \mathrm{I}^{-1}$ and with the cross-linked pulp, whatever its concentration, this feature disappeared. The atypical behaviour of the sorption of $\mathrm{Ca}^{2+}$ may be attributed to the lower number of ionic sites of the raw pulp (Fourest and Volesky, 1996) and/or to the steric role played by acetyl groups in the case of the more weakly bound cations. The presence of acetyl groups has been shown to decrease the affinity of various substrates towards divalent metal cations: chitin (Guibal et al., 1995), acetylated alginates (Lee et al., 1996) and sugar-beet pectins (Dronnet et al., 1996).

The following clear scale of selectivity was obtained for both modified pulps: $\mathrm{Cu}^{2+} \sim \mathrm{Pb}^{2+} \gg \mathrm{Zn}^{2+} \sim \mathrm{Cd}^{2+}>\mathrm{Ni}^{2+}>$ $\mathrm{Ca}^{2+}$. It was similar to the selectivity order shown with extracted pectins (Dronnet et al., 1996), the raw beet pulp 
(Dronnet et al., 1997) and for other biosorbents which carry carboxyl functions or other ionic functions (Marshall et al., 1993; De Carvalho et al., 1994; Crist et al., 1994; Volesky and Holan, 1995; Akthar et al., 1996). Treatments such as alkaline saponification or cross-linking by epichlorohydrin did not alter the ionic selectivity order. Kohn et al. (1976) also did not detect modification of the selectivity scale after cross-linking with epichlorohydrin.

\section{Loss of GalA during sorption experiments}

In order to show the stability of the sorbent structure and its CEC, the loss of GalA by aqueous extraction during sorption experiments was monitored. In the case of the raw and the saponified forms of the pulp, the loss of galacturonic acid decreased when $\left[\mathrm{Me}^{2+}\right]_{1} /\left[C_{\mathrm{p}}\right]$ increased, i.e. when the sorption increased. The percentage of extracted galacturonic acid then increased slightly when $\left[\mathrm{Me}^{2+}\right] /\left[\mathrm{C}_{\mathrm{p}}\right]$ reached the value corresponding to the plateau of the sorption isotherm. This variation was not observed with cross-linked pulp, the loss of GalA stayed the same whatever the value of $\left[\mathrm{Me}^{2+}\right] /$ $\left[C_{p}\right]$. Results reported in Table 2 correspond to the minimum loss value for a given ratio of $\left[\mathrm{Me}^{2+}\right] /\left[C_{p}\right]$ depending on the cation (raw and saponified forms) or to the average loss value whatever the amount of metal cation (crosslinked pulp). Values of the loss of galacturonic acid are aiso given when no metal cation was added.

When no divalent metal cation was added, the loss was mucll higher, confirming that ionic cross-linking is induced by the presence of divalent cations (Dronnet et al., 1997a). The loss of GalA did not depend on the nature of the metal cation added to the sorbent. After modification even for the cross-linked pulp, the loss of GalA increased, while a decrease was expected, which might indicate that the solubilised GalA corresponded in this case to low molecular weight molecules arising from the degradation of pectins induced by the different chemical treatments. However, no variation of the loss of galacturonic acid was observed according to the amount of added metal cations after the cross-linking treatment. The higher the sorbent concentration the lower the loss of galacturonic acid whatever

Table 2. Galacturonic acid loss of the sorbent in percentage of the initial galacturonic acid content

\begin{tabular}{|c|c|c|c|c|c|}
\hline & \multicolumn{5}{|c|}{ Form of the pulp $\left(\mathrm{g}^{-1}\right)$} \\
\hline & \multicolumn{2}{|c|}{$\mathrm{Raw}^{\prime \prime}$} & \multirow{2}{*}{$\frac{\text { Saponified }^{\prime \prime}}{14.6}$} & \multicolumn{2}{|c|}{ Cross-linked $b$} \\
\hline & 3.4 & 14.6 & & 7.5 & 14.6 \\
\hline No cution & 4.8 & 3.7 & 5.8 & 4.3 & 2.6 \\
\hline $\mathrm{Ca}^{2+}$ & 1.7 & 0.8 & 2.6 & 4.3 & 2.4 \\
\hline $\mathrm{Ni}^{2+}$ & 1.5 & 0.8 & 2.2 & 4.4 & 2.5 \\
\hline $\mathrm{Cd}^{2+}$ & 1.1 & 0.8 & 2.5 & 4.4 & 2.7 \\
\hline $\mathrm{Zn}^{2+}$ & 1.1 & 0.8 & 2.5 & 4.5 & 2.4 \\
\hline $\mathrm{Pb}^{2+}$ & 1.2 & 1.1 & 2.6 & 4.4 & 2.4 \\
\hline $\mathrm{Cu}^{2+}$ & 1.0 & 0.9 & 2.7 & 4.3 & 2.4 \\
\hline
\end{tabular}

"Minimum value

${ }^{b}$ Average value the form of the pulp. It may be related to slower stirring when the quantity of pulp was increased, since the same stirring power was used in both cases. The release of some water-soluble material (alginate) during sorption experiments of $\mathrm{Pb}^{2+}$ by algae was also noted (Holan and Volesky, 1994; De Carvalho et al., 1994).

\section{Sorption models}

The Freundlich model is valid for a monolayer sorption model on a surface containing a finite number of sites with mutual interactions between sorbed metal cations. On the contrary, the Langmuir-type model presupposes homogeneity of the sorbing surface and no interactions, involving uniform energies of sorption on the surface and no transmigration of metal cations in the plane of the surface.

The experimental data for the metal cation sorption by the modified pulp at $14.6 \mathrm{~g} \mathrm{l}^{-1}$ are represented in the form of the Langmuir isotherm in Fig. 3. From these plots, isotherm constants were derived by performing linear regression on each set of data (Table 3 and Table 4 for the saponified and the cross-linked pulp, respectively). Values of the ratio
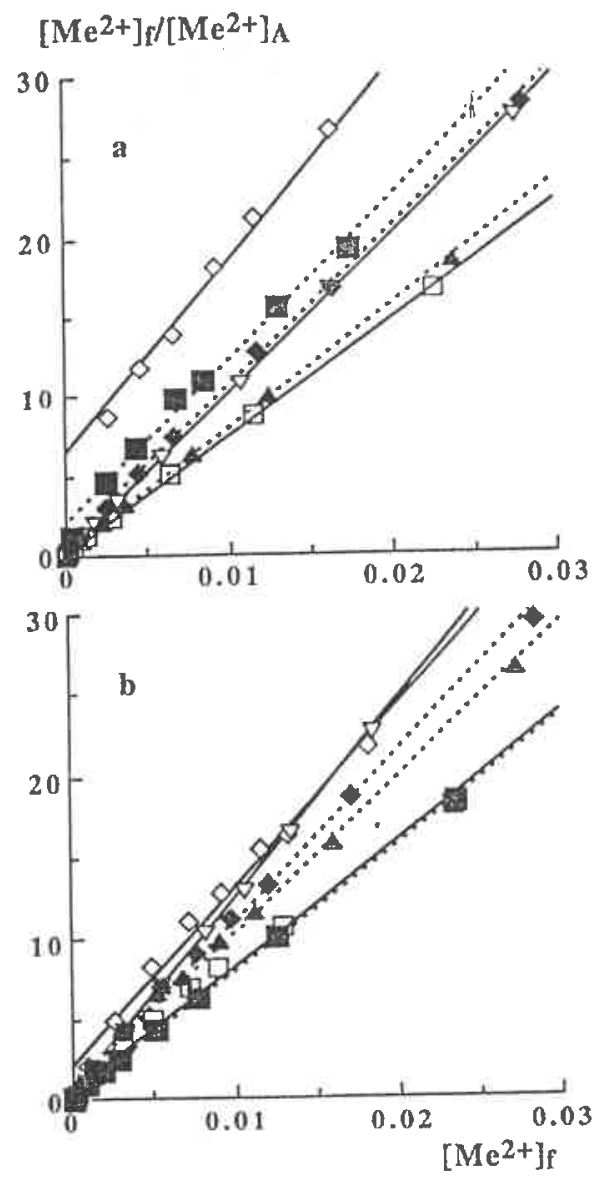

Fig. 3. Langmuir-type isotherms of the binding of cations by the pulp at $14.6 \mathrm{~g} \mathrm{I}^{-1}$ in $0.1 \mathrm{~mol}^{-1} \mathrm{NaNO}_{3}$, at $25^{\circ} \mathrm{C}$ and at an initial $\mathrm{pH} \sim 7.2:(\square) \mathrm{Cu}^{2+},(\mathbf{a i}) \mathrm{Pb}^{2+},(\diamond) \mathrm{Zn}^{2+},(\nabla) \mathrm{Cd}^{2+},(\Delta) \mathrm{Ni}^{2+},(\diamond)$ $\mathrm{Ca}^{2+} ;(a)$ saponified pulp and $(b)$ cross-linked pulp. Filled lines for $\mathrm{Cu}^{2+}, \mathrm{Cd}^{2+}$ and $\mathrm{Ca}^{2+}$; dashed lines lor $\mathrm{Pb}^{2+}, \mathrm{Zn}^{2+}$ and $\mathrm{Ni}^{2+}$ 
Table 3. Langmuir parameters of the binding of divalent metal cations by the saponified pulp

\begin{tabular}{|c|c|c|c|c|c|c|c|c|c|c|c|c|}
\hline \multirow{2}{*}{$\frac{\text { Cation }}{\left[C_{\mathrm{p}}\right]\left(\mathrm{g}^{-1}\right)}$} & \multicolumn{2}{|l|}{$\mathrm{Ca}^{2+}$} & \multicolumn{2}{|l|}{$\mathrm{Ni}^{2+}$} & \multicolumn{2}{|l|}{$\mathrm{Zn}^{2+}$} & \multicolumn{2}{|l|}{$\mathrm{Cd}^{2+}$} & \multicolumn{2}{|l|}{$\mathrm{Pb}^{2+}$} & \multicolumn{2}{|l|}{$\mathrm{Cu}^{2+}$} \\
\hline & 7.1 & 14.6 & 7.1 & 14.6 & 7.1 & 14.6 & 7.1 & 14.6 & 7.1 & 14.6 & 7.1 & 14.6 \\
\hline$K_{\mathrm{L}}\left(1 \mathrm{eq}^{-1}\right)$ & - & 185 & 1360 & 505 & 1285 & 1240 & 1710 & 1320 & 4440 & 2930 & 4730 & 3740 \\
\hline $\begin{array}{l}\mathrm{Me}_{\mathrm{A}} \max \\
\left(\text { meq }^{-1}\right)\end{array}$ & - & 0.83 & 0.60 & 0.97 & 0.91 & 1.01 & $1.1^{5}$ & 1.11 & 1.17 & 1.28 & 1.30 & 1.35 \\
\hline $\mathrm{Me}^{2} \mathrm{Amax} / \mathrm{CEC}$ & - & $\begin{array}{l}0.73 \\
0.997\end{array}$ & $\begin{array}{l}0.54 \\
0.999\end{array}$ & $\begin{array}{l}0.86 \\
0.996\end{array}$ & $\begin{array}{l}0.81 \\
0.998\end{array}$ & $\begin{array}{l}0.89 \\
0.999\end{array}$ & $\begin{array}{l}0.95 \\
0.999\end{array}$ & $\begin{array}{l}1.00 \\
0.998\end{array}$ & $\begin{array}{l}1.04 \\
0.999\end{array}$ & $\begin{array}{l}1.13 \\
0.999\end{array}$ & $\begin{array}{l}1.15 \\
0.998\end{array}$ & $\begin{array}{l}1.20 \\
0.998\end{array}$ \\
\hline
\end{tabular}

$\mathrm{Me}_{\mathrm{b}} \mathrm{max} / \mathrm{CEC}$ are also presented and allow the degree of saturation of the ionic sites to be evaluated. The same data are shown as Freundich isotherm in Fig. 4 for both forms of pulp at $14.6 \mathrm{~g} \mathrm{l}^{-1}$. Previous results of the sorption of metal cations on raw beet pulp (Dronnet et al., 1997) were also fitted according to the Freundlich equation.

The Langmuir theory was found to best represent the sorption of divalent metal cations onto modified pulps over the entire solute concentration range adopted in experimental studies as was supported by consulting $r^{2}$ values generated by linear regressions. Indeed, the Freundlich equation predicts that the metal ion concentration on the sorbent will increase as long as there is an increase in the metal ion concentration while experimental results showed a plateau indicating a limiting value of the sorption. Therefore, in spite the high metal cation sorption occurring with such substrates, sorption resulting from a monolayer sorption appeared not to be disturbed by lateral interactions between sorbed metals distributed according to homogeneous sorption energies. The sorption of $\mathrm{Cd}^{2+}, \mathrm{Cu}^{2+}$ and $\mathrm{Zn}^{2+}$ onto lignite was found to be best modelled by the Langmuir theory (Allen and Brown, 1995) while sorption of uranium fitted well according to the Freundlich isotherm (Guibal et al., 1995). The sorption of $\mathrm{Cr}^{3+}$ by a cyanobacterium did not fit the Langmuir-type isotherm unlike that of some divalent metal cations such as $\mathrm{Pb}^{2+}$ or $\mathrm{Ni}^{2+}$ (Sampedro et al., 1995), suggesting that uptake of trivalent cations induces different sorption mechanisms.

\section{Freundlich's sorption model}

As shown in Fig. 4, curved isotherms were found according to the Freundlich's sorption model, suggesting that it was not applicable over the entire solute concentration range. Linear regions were observed on each isotherm but did not correspond to the same range of data according to the metal cation. Such a trend was also valid for the raw beet pulp (not shown). This was also found by Allen and Brown (1995) when studying the metal sorption onto lignite. These authors observed different distinct linear parts within individual set of data and then performed multiple regressions on different ranges of the data in order to obtain reliable values.

Linear regression of experimental data from the Freundlich model precluded reliable values for Freundlich parameters and then was not applied. Multiple regressions of the data were also not applied since linear regions on isotherm depend on the metal cation.

Langmuir's sorption model

1

As a consequence of the higher applicability of the Langmuir model, the trends of the sorption parameters according to the nature of the metal cation, the $\mathrm{pH}$ (Dronnet et al., 1997) and the sorbent concentration are best appreciated by studying the Langmuir-type isotherm parameters.

$K_{L}$ and $\mathrm{Me}_{1} \max$ values varied together according to the nature of the metal cation. When they are compared, the same decreasing selectivity order for both modified pulps can be drawn as follows: $\mathrm{Cu}^{2+} \geq \mathrm{Pb}^{2+}>\mathrm{Cd}^{2+} \sim \mathrm{Zn}^{2+}>$ $\mathrm{Ni}^{2+}>\mathrm{Ca}^{2+}$. It confirms the selectivity order already observed from the initial sorption isotherms. However, slight variations may be observed between $K_{\mathrm{L}}$ and $\mathrm{Me}_{\mathrm{A}} \max$, especially with $\mathrm{Cd}^{2+}$ and $\mathrm{Zn}^{2+}$. Sorption of metals by a cyanobacterium was characterised by a similar selectivity scale $\left(\mathrm{Pb}^{2+}>\mathrm{Cu}^{2+}>\mathrm{Zn}^{2+}>\mathrm{Cd}^{2+}>\mathrm{Ni}^{2+}\right)$ drawn from $\mathrm{Me}_{\mathrm{b}}$ max values, while $\mathrm{Cu}^{2+}$ and $\mathrm{Cd}^{2+}$ are inverted when $K_{\mathrm{L}}$ values were observed (Sampedro et al., 1995).

Whatever the metal cation, $K_{\mathrm{L}}$ decreased with increasing sorbent concentration for both modified pulps. $K_{\mathrm{L}}$ values

Table 4. Langmuir parameters of the binding of divalent metal cations by the pulp cross-linked by epichlorohydrin

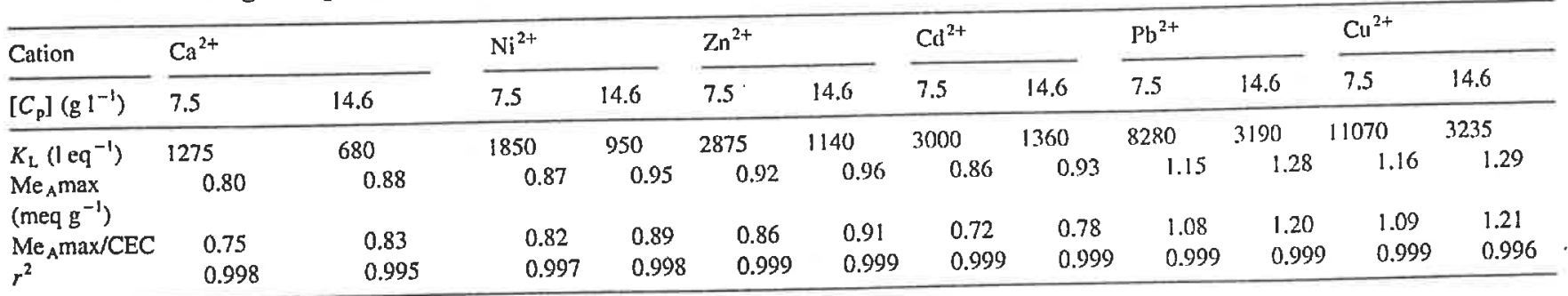



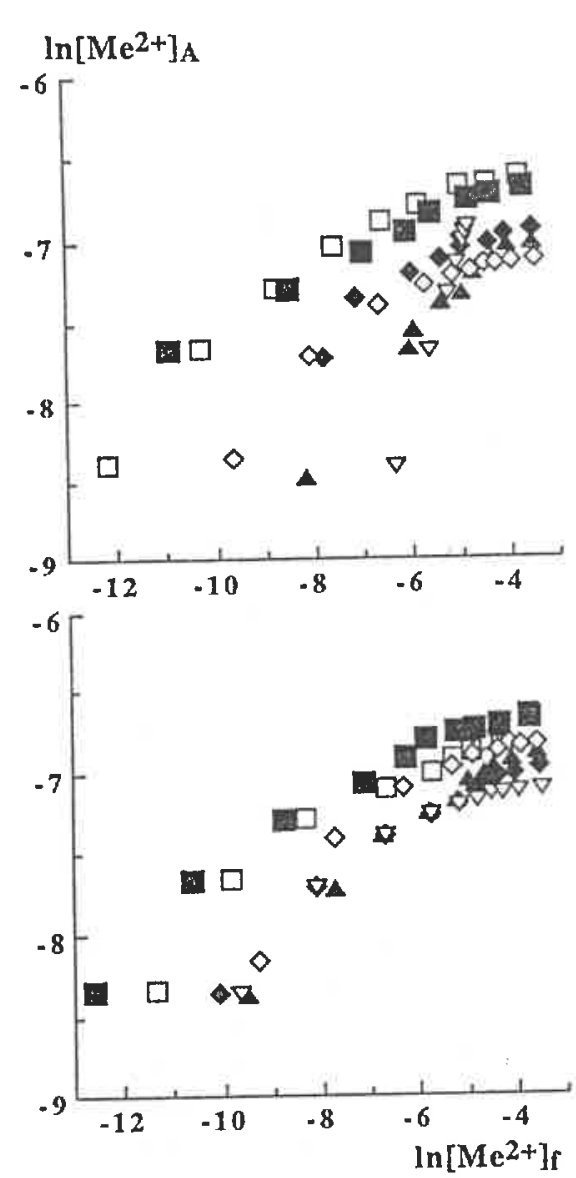

Fig. 4. Freundlich-lype isotherms of the binding of cations by the pulp at $14.6 \mathrm{~g} \mathrm{l}^{-1}$ in $0.1 \mathrm{~mol}^{-1} \mathrm{NaNO}_{3}$, at $25^{\circ} \mathrm{C}$ and at an initial pH 7.2: (口) $\mathrm{Cu}^{2+},(\Delta) \mathrm{Pb}^{2+},(\diamond) \mathrm{Zn}^{2+},(\nabla) \mathrm{Cd}^{2+},(\Delta) \mathrm{Ni}^{2+},(\diamond)$ $\mathrm{Ca}^{2+} ;(a)$ saponified pulp and $(b)$ cross-linked pulp

were found to decrease with increasing raw pulp concentration only in the case of the two more strongly bound cations, i.e. $\mathrm{Cu}^{2+}$ and $\mathrm{Pb}^{2+}$ (Dronnet et al., 1997). $K_{\mathrm{L}}$ varied after modification according to the nature of the metal cation: it increased drastically for $\mathrm{Ca}^{2+}, \mathrm{Ni}^{2+}$ and $\mathrm{Cd}^{2+}$ but decreased with others. $K_{\mathrm{L}}$ values stayed similar with the saponified and cross-linked forms. The increase in binding sites was thus mainly responsible for such an increase while cross-linking seemed to play a greater role with the more weakly bound cations, i.e. $\mathrm{Ca}^{2+}$ and $\mathrm{Ni}^{2+} . K_{\mathrm{L}}$ decreased when the sorption of $\mathrm{Ni}^{2+}$ and $\mathrm{Pb}^{2+}$ was conducted with formaldehyde-treated algae and this decrease was more marked after treatment by epichlorohydrin (Holan and Volesky, 1994). However, it increased in the case of $\mathrm{Cd}^{2+}$ uptake (Holan et al., 1993).

The higher the sorbent concentration the higher the sorption capacity (higher $\mathrm{Me}_{\mathrm{b}} \max$ value). This was already observed with initial sorption isotherms, suggesting the higher occupancy of binding sites. Indeed, modified pulps had $\mathrm{Me}_{\mathrm{b}} \mathrm{max}$ values approximately twice those of the raw beet pulp (Dronnet et al., 1997) in agreement with the increased CECs. $\mathrm{Zn}^{2+}$ and $\mathrm{Cd}^{2+}$ uptake by yeast cell-wall increased after alkali treatment ( 15 and $25 \%$ starting from the initial form, respectively) and treatment by formaldehyde (60 and $75 \%$ starting from the initial form, respectively) (Ting and Teo, 1994). Studying the sorption of $\mathrm{Ni}^{2+}$ or $\mathrm{Pb}^{2+}$ by algae, Holan and Volesky (1994) showed that $\mathrm{Me}_{\mathrm{b}} \mathrm{max}$ increased when biomass was formaldehyde treated $\left(83 \%\right.$ to reach $1.5 \mathrm{meq} \mathrm{g}^{-1}$ for $\mathrm{Ni}^{2+}$ and $58 \%$ to reach 3.5 meq g ${ }^{-1}$ for $\mathrm{Pb}^{2+}$ starting from the initial biomass) while swelling capacity was strongly reduced, but decreased after treatiment by epichlorohydrin (up to $0.67 \mathrm{meq} \mathrm{g}^{-1}$ ). However, biosorption of cadmium by some algae was decreased after treatment by formaldehyde (31\% starting from the raw form) (Holan et al., 1993) while SC was strongly decreased $(60 \%)$. Maranon and Sastre (1992) increased the sorption capacity of lignocellulosic apple residues (4-fold) by treating with phosphorus(V) oxychloride, while swelling was reduced by 1.6 times to reach $7.1 \mathrm{ml} \mathrm{g}^{-1}$.

Despite a decreased specific surface area (down to $0.96 \mathrm{~m}^{2} \mathrm{~g}^{-1}$, i.e. $30 \%$ of that of raw pulp), metal-binding capacity was greatly improved after saponification and/or cross-linking, suggesting that surface adsorption contributes only a small part to the sorption phenomenon and that ionexchange is the major mechanism involved when divalent metal cations are bound by beet pulp. Ting et al. (1995) also found that gold uptake onto Chlorella vulgaris increased after treatment with alkali reagents (25\%) and after crosslinking with formaldehyde $(52 \%)$ while specific surface area was notably reduced: 40 and $32 \%$ of that of the initial form for alkali-treated and formaldehyde-treated substrates, respectively.

Values of $\mathrm{Me}_{\mathrm{A}} \mathrm{max} / \mathrm{CEC}$ obtained for $\mathrm{Pb}^{2+}$ and $\mathrm{Cu}^{2+}$ exceeded 1 , indicating that the binding of these divalent cations was higher than the stoichiometry predicted from the one $\mathrm{Me}^{2+}$ to two $\mathrm{COO}^{-}$ratio. They were always lower than or equal to 1 for the other metal cations. This was already found with the raw pulp (Dronnet et al., 1997) and was not affected by increasing CEC and/or by crosslinking. The complexation of $\mathrm{Cu}^{2+}$ and $\mathrm{Pb}^{2+}$ by nearby hydroxyl functions in addition to one carboxyl function would explain the higher affinity for pectins carried by beet pulp as well as the fact that $\mathrm{Me}_{\Lambda} \max / \mathrm{CEC}$ can be higher than 1 .

\section{CONCLUSION}

No change of the selectivity scale wals induced by treating beet pulp with alkaline or cross-linking reagents, so that the same order of affinity: $\mathrm{Cu}^{2+} \geq \mathrm{Pb}^{2+} \gg \mathrm{Zn}^{2+} \sim \mathrm{Cd}^{2+}>\mathrm{Ni}^{2+}$ $>\mathrm{Ca}^{2+}$ as for extracted pectins (Dronnet et al., 1996) and for raw beet pulp (Dronnet et al., 1997) was obtained. However, the difference between sorption isotherms became less marked after such treatments as the sorption of the more weakly bound cations was increased to a greater extent than that of $\mathrm{Cu}^{2+}$ and $\mathrm{Pb}^{2+}$. The Langmuir theory was found to represent better than the Freundlich approach the sorption of all divalent metal cations onto raw and modified 
pulp over the range of metal cation concentrations applied, indicating that the sorption of divalent metal cations by raw and modified pulp would proceed without any interactions between sorbed cations and on sites presenting homogeneous sorption energies. The sorption of $\mathrm{Ca}^{2+}$ could be fitted adequately to the Langmuir model only at high concentration of saponified pulp. This could be related to the higher affinity of $\mathrm{Ca}^{2+}$ for unacetylated pectins (Dronnet et al., 1996) and/or to the need for many ionic sites to cause significant sorption (Holan and Volesky, 1994). As with raw beet pulp (Dronnet et al., 1997), sorption was found to increase with the substrate concentration, while values of the sorption constant decreased, notably for the more strongly bound cations. Modifications allowed an increase in the metal-binding properties due to an increase of the number of anionic sites, i.e. methylester-free galacturonosyl units carried by pectins, while the specific surface area decreased.

Other interactions than pure electrostatic interactions, which would only occur with the more weakly bound cations, would contribute to the sorption of $\mathrm{Cu}^{2+}$ and $\mathrm{Pb}^{2+}$, explaining their higher affinity for pectins inside cell-walls and the fact that the ratio $\mathrm{Me}_{\mathrm{A}} \max / \mathrm{CEC}$ may be higher than 1. Hydroxyl functions close to carboxyl functions would participate in the complexation of such highly bound cations and allow the participation of less than two carboxyl functions to hold one divalent cation.

Such treatments to enhance the metal-binding performances increase the cost of readily available beet-pulp based ion-exchanger. Two different ways to use such substrates could be suggested. Beet-pulp could be extensively used in its riw form without recycling due to its very low cost. On the other hand, cross-linked beet-pulp could be used like a synthetic resin with sorption/desorption cycles since the cell-wall structure is reinforced (the aqueous extraction of galacturonic acid during WRC experiments was strongly decreased).

\section{ACKNOWLEDGEMENTS}

The authors thank Dr. I.D. Pulford for correcting the English.

\section{REFERENCES}

Akthar, M.D., Sastry, K.S., Mohan, P.M. (1996) Mcchanism of metal ion biosorption by fungal biomass Biometals, 9, 21-28.

Allen, S.J., Brown, P.A. (1995) Isotherm analyses for single component and multi-component metal sorption onto lignile $J$. Chem. Terh. Biotecinol., 62, 17-24.

Bertin, C., Rouau, X., Thibault, J.-F. (1988) Structure and properties of sugar beet fibres J. Sci. Food Agric., 44, 15-29.

Brunauer, S. (1945) The Adsorption of Gases and Vapors, Vol. 1. Princeton University Press. Princeton, NJ.

Chang, J.-S., Hong, J. (1996) Biosorption of mercury by the inactivated cells of Pseudomonas aeruginosa PU21 (Rip64). Biotechnol. Bioeng., 44, 999-1006.
Crist, D.R. Crist, R.H., Martin, J.R., Watson, J.R. (1994) Ion exchange systems in proton-metal reactions with algal cell wal!s FEMS Microbiol. Rev., 14, 309-314.

De Carvalho, R.P., Chong, K.-H., Volesky, B. (1994) Effects of leached alginate on metal biosorption Biotechnol. Letl., 16, 875-880.

Dronne, V.M., Renard, C.M.G.C., Axelos, M.A.V., Thibault, J.-F. (1996) Characterisation and selectivity of divalent metal ions binding by citrus and sugar-hect pectins Carbohydr, Polym., 30, 253-263.

Dronnet, V. M. Renard, C. M. G. C. Axclos, M. A. V., \& Thibault, J.-F. (1907). Binding of divalent metal cations by sugar-bet pulp Carboh)dr. Polym.34, 73-82.

Dronnet, V. M., Axclos, M. A. V., Renard, C. M. G. C., \& Thibault, J.-F. (1998). Improvement of the binding capacity of metal cations by sugarbect pulp. 1. Impact of cross-linking treatments on the composition, the hydration and binding properties. Carbolydr. Polym., submilted.

Fourest, E., Volesky, B. (1996) Contribution of sulfonate groups and algimate to heavy metal biosorption by the dry hiomass of Sargussum fliniloms.

Guibal, E., Roulph, C., Le Cloirec, P. (1992) Uranium biosorption by a filamentous fungus Mucor miehei pH effect on mechanisms and performances of uptake Water Res., 8, 1139-1145.

Guibal, E., Jansson-Charrier, M., Saucedo, I., Le Cloirec, P. (1995) Enluncement of metal ion sorption perlormances of chitosan: effects of the structure on the diffusion properties Langmuir, 11, 59 i-598.

Holan, Z.R., Volesky, B. (1994) Biosorption of lead and nickel by biomass of marine algae Biotechnol. Bioeng., 43, 1001-1009.

Holan, Z.R., Vstesky, B., Prasctyo, l. (1993) Biosorption of cadmium by biomass of matrine algae Biolechmol. Bioeng., 41, 819-825.

Huber, A. L., Holbein, B. E., \& Kidby, D. K (1990). Metal uptake by Huber, A. L., Holbein, B. E., \& Kidoy, D. K. Volesky (Ed.), Biosorption of Heavy Metals. Boca Raton, FL: CRC Press, pp. 249-292.

Kohn, R. Rexova-Benkova, L., Luknar, O., Kuniak, L. (1976) Crosslinked pectic acid. The effects of cross-linking on cation exchange, binding ol endopolygalacturonase and biodegradability Coll. Czech. Chem. Commun., 41, $1879-1893$.

Kumar, P. Dara, S.S. (1982) Utilisation of agricultural wastes for decontaminating industrial/domestic wastewaters from loxic metals Agric: Wastes, 4, 213-223.

Kuniak, L., Marchessault, R.H. (1972) Study of cross-linking reaction between epichlorohydrin and starch Starch/Stärke, 4, 110-116.

Langmuir, I. (1918) The adsorption of gases on plane surfaces of glass, mica and platinum $I$. Am. Chem. Soc., 40, 1361-1403.

Langenhorst, W.Th.J.P., Tels, M., Vlugter, J.C., Waterman, H.I. (1961) Cation exchangers on a sugar-beet pulp base. Application for decontaminating radiaactive wastewater J. Biochem. Microbiol. Technol. Eng., 3. $7-20$.

Lce, J.W., Asliby, R.D., Day, D.F. (1996) Role of acetylation on melal induced precipilation of alginates Carbohydr. Polym., 29. $337-345$.

MacConnell, A.A., Eastwood, M.A., Mitchell, W.D. (1974) Physical characterisation al vegetable foodstufts that could influence bowel function J. Sci. Ford Agrie., 25, 1457-1464.

Maramon, E., Sustrc, H. (1992) Beluviour of lignocellulosic apple residues in the sorption of trace metals in packed beds React. Polym., 18, 173176.

Marshall, W.E., Champagne, E.T., Evans, W.J. (1993) Use of rice milling byproducts (hulls \& bran) to remove metal ions from aqueous solution J. Environ. Sci. Healh A28, 1977-1992.

Renard, C.M.G.C., Crépeau, M.-J., Thibault, J.-F. (1994) Influence of ionic strength, $\mathrm{pH}$ and dielectric constant on hydration properties of native and modified fibres from sugar-beet and wheat bran Ind. Crops Products, 3, 75-84.

Sampedro, M.A., Blinco, A., Llama, M.J., Serra, J.L. (1995) Sorption of heavy metals to Phormidium laminosum biomass Biotechnol. Appl. Biochem., 22, 355-366.

Sharma, D.C., Forster, C.F. (1994) A preliminary examination into the 
adsorption of hexavalent chromium using low-cost adsorbents Biores. Technol., 47, 257-264.

Thibault, J.-F. (1979) Automatisation du dosage des substances pectiques par la méthode au méta-hydroxybiphenyl Lebensm. Wiss. Technol., 12, 247-251.

Ting, Y.P., Teo, W.K. (1994) Uptake of cadmium and zinc by yeast: effects of co-metal ion and physical/chemical trentments Biores. Technol., 50, 113-117.

Ting. Y.P., Teo, W.K., Soh, C.Y. (1995) Gold uptake by Chlorella vilgaris J. Appl. Phycol., 7, 97-100.
Vazquez, G., Antorrena, G., Gonzalez, J., Doval, M.D. (1994) Adsorption of heavy metal ions by chemically modified Pinus pinaster bark Biores. Technol., 48, 251-255.

Volesky, B. (1990), Removal and recovery of heavy metals by biosorption. In: B. Volesky Ed.), Biosorption of Heavy Metals. Boca Raton, FL: CRC Press, pp. 7-43.

Volesky, B., Holan, Z.R. (1995) Biosorption of henvy metals Biotechnol. Prog., 11, 235-25i. 